\title{
Neonatal outcomes after influenza immunization during pregnancy: a randomized controlled trial
}

\author{
Mark C. Steinhoff MD, Saad B. Omer PhD, Eliza Roy DCH, Shams El Arifeen DrPH, Rubhana Raqib PhD, \\ Caitlin Dodd MS, Robert F. Breiman MD, K. Zaman PhD
}

\begin{abstract}
Background: There are limited data about the effect of maternal influenza infection on fetuses and newborns. We performed a secondary analysis of data from the Mother'sGift project, a randomized study designed to test the effectiveness of inactivated influenza and pneumococcal vaccines during pregnancy.
\end{abstract}

Methods: In the Mother'sGift project, 340 pregnant women in Bangladesh received either inactivated influenza vaccine or 23valent pneumococcal polysaccharide vaccine (control). This study was performed from August 2004 through December 2005. We performed a secondary analysis of outcomes following maternal influenza immunization during two periods: when influenza virus was not circulating (September 2004 through January 2005) and when influenza virus was circulating (February through October 2005). We assessed gestational age, mean birth weight and the proportion of infants who were small for gestational age.

Results: During the period with no circulating influenza virus, there were no differences in the incidence of respiratory illness with fever per 100 person-months among mothers and infants in the two groups (influenza vaccine: 3.9; control: $4.0 ; p>0.9$ ). The proportion of infants who were small for gestational age and the mean birth weight were similar between groups (small for gestational age: influenza vaccine $29.1 \%$, control $34.3 \%$; mean birth weight: influenza vaccine $3083 \mathrm{~g}$, control $3053 \mathrm{~g}$ ). During the period with circulating influenza virus, there was a substantial reduction in the incidence per 100 person-months of respiratory illness with fever among the mothers and infants who had received the influenza vaccine (influenza vaccine: 3.7 ; control: $7.2 ; p=0.0003)$. During this period, the proportion of infants who were small for gestational age was lower in the influenza vaccine group than in the control group $(25.9 \% \mathrm{v}$. $44.8 \% ; p=0.03)$. The mean birth weight was higher among infants whose mothers received the influenza vaccine than among those who received the control vaccine during this period (3178 g v. $2978 \mathrm{~g} ; p=0.02$ ).

Interpretation: During the period with circulating influenza virus, maternal immunization during pregnancy was associated with a lower proportion of infants who were small for gestational age and an increase in mean birth weight. These data need confirmation but suggest that prevention of influenza infection in pregnancy can influence intrauterine growth.

Trial Registration: ClinicalTrials.gov: NCT 00142389
Competing interests: Mark Steinhoff has served as a consultant for Merck. No competing interests declared by any other authors.

This article was peer reviewed.

Correspondence to: Dr. Mark C. Steinhoff, mark.steinhoff@cchmc.org

CMAJ 2012. DOI:10.1503 /cmaj.110754
I nfluenza infection in young infants is common and results in high rates of hospital admission, ${ }^{1}$ but infection can be prevented by immunization of the mother during pregnancy. ${ }^{2}$ There are few prospective studies of the effect of antenatal vaccination against influenza on fetal and neonatal outcomes. ${ }^{3}$ There is conflicting information about the effect of maternal influenza infection on the fetus and newborn, ${ }^{3}$ though other antepartum maternal infections have well-described adverse effects on the fetus. ${ }^{4}$

The Mother'sGift project is a randomized trial designed to assess the safety and efficacy of maternal pneumococcal and influenza immunization in Bangladesh. The primary outcomes of this study have been reported. ${ }^{2}$ In the current article, we report the results of a secondary analysis to assess the hypothesis that influenza immunization influences the outcomes of infants whose mothers were exposed to influenza during pregnancy.

\section{Methods}

\section{Study participants and design}

This study was carried out from August 2004 through December 2005. The study design and primary analysis have been reported. ${ }^{2}$ Briefly, we randomly assigned 340 healthy pregnant women in the third trimester to receive either trivalent inactivated influenza vaccine (Fluarix; 2004, South hemisphere formulation) or the 23-valent pneumococcal polysaccharide vaccine (Pneu- 
movax $){ }^{2}$ Figure 1 provides the details of each study group. The women were interviewed at home each week from the time of immunization until six months after delivery. We recorded all respiratory illnesses, and infant illnesses were assessed by use of a rapid influenza antigen test. ${ }^{2}$

The randomization sequence was generated by computer and was stratified by clinic and blocked in groups of four. Sequentially numbered opaque envelopes containing the study group assignments were provided to the recruitment clinics. Clinic nurses, who were not involved in the collection of project data, performed the immunizations. Mothers, families and study staff who collected illness and other data were unaware of the study group assignments.

\section{Ethics approval}

The protocol was approved by the institutional review boards of the International Centre for Diarrheal Disease Research, Bangladesh, and the Bloomberg School of Public Health at Johns
Hopkins University. The use of commercial vaccines licensed by the US Food and Drug Administration was approved by the Directorate of Drug Administration of the Government of the People's Republic of Bangladesh. Mothers and fathers provided signed informed consent.

\section{Statistical analysis}

\section{Sample size}

The primary goal of this study was to assess the immunogenicity of pneumococcal vaccine in mothers and infants, and influenza vaccine was chosen as the comparator. ${ }^{2}$ A sample size of 170 mothers and their infants in each group was chosen to provide adequate power for the primary outcomes of the study and to detect a $30 \%$ reduction of illness. ${ }^{2}$

\section{Outcomes}

The outcomes included in the present analysis were the proportion of infants who were small

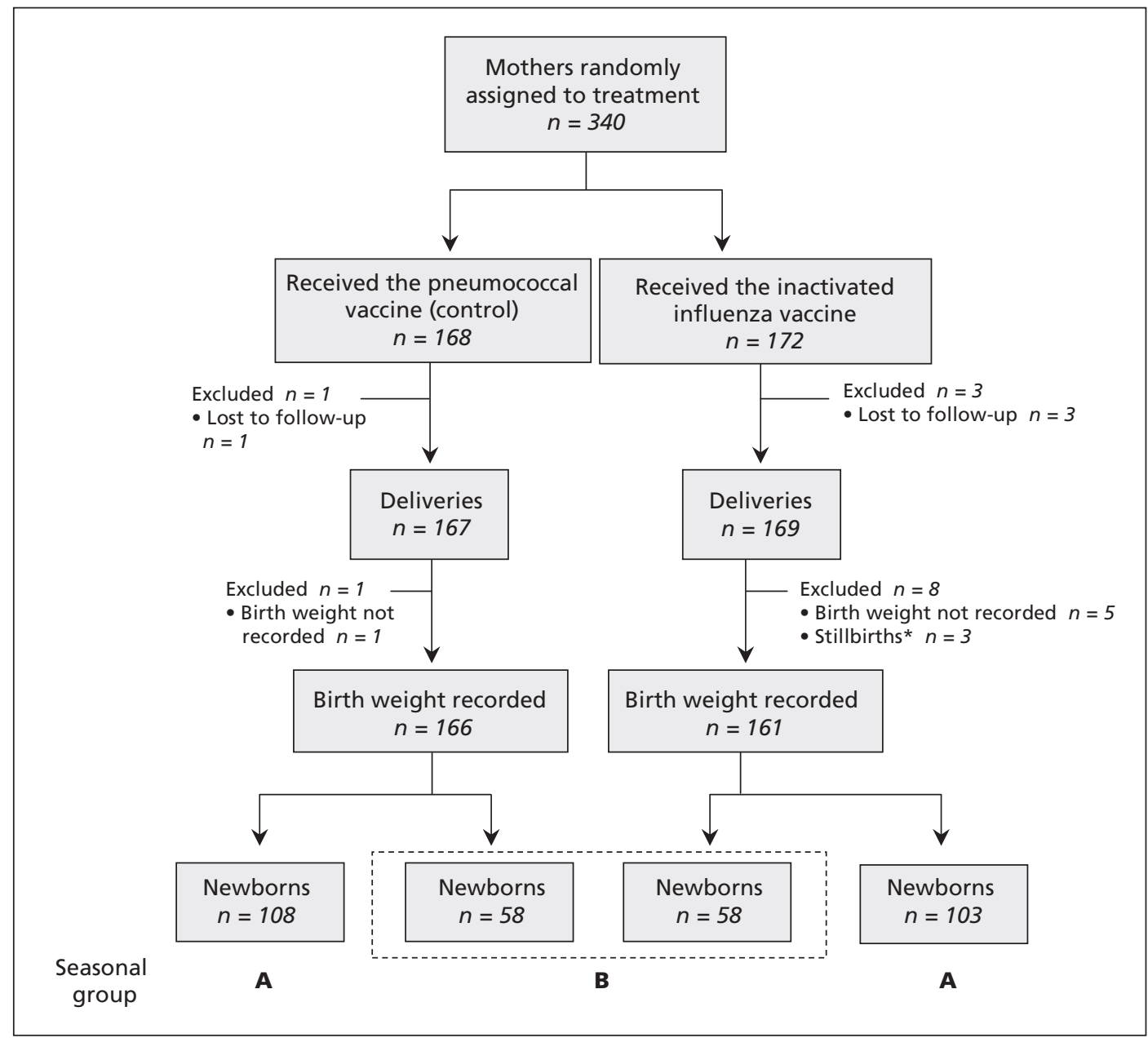

Figure 1: Flow of mothers and infants through the study. *Stillbirths occurred in December 2004, January and February 2005. There was no difference in the number of stillbirths between groups (Fisher exact test $p=0.3$ ). Periods of influenza virus circulation: A) limited circulation, September 2004 through January 2005; B) confirmed circulation, February through October 2005. 
for gestational age $(<10$ th percentile weight for gestational age ${ }^{5}$, mean birth weight (as recorded in the delivery record), the proportion of infants with a low birth weight $(<2500 \mathrm{~g})$, gestational age and the proportion of premature births $(<37$ weeks gestation). We calculated gestational age from the reported first day of the last menstrual period. There is no Bangladesh-specific reference for weight for gestational age, so we used a North American standard. ${ }^{5}$ We also compared weight for gestational age using a global reference standard for growth developed by the World Health Organization; this standard was designed for use with full-term infants. ${ }^{6}$

\section{Analysis}

To compare outcomes between study groups, we calculated odds ratios (ORs) and we assessed differences in group means using the Student $t$ test and the Mann-Whitney $U$ test. We assessed proportions using the $\chi^{2}$ and Fisher exact tests. All tests were two-sided. We also calculated ORs for outcomes adjusted for selected characteristics (gestational age at vaccination, interval between immunization and birth) using multiple logistic and linear regression.

\section{Classification of analytical study intervals} In our initial report, ${ }^{2}$ we used a rapid test to document the circulation of the influenza virus in Dhaka, Bangladesh, from January through October 2005. An independent local influenza surveillance study in Dhaka isolated influenza viruses in children with febrile respiratory illnesses from early 2004 through December $2007,{ }^{7}$ and they reported very few influenza viruses among ill children between September 2004 and January 2005. Some influenza virus isolates were reported during February and March, and a substantial number of influenza $\mathrm{A} / \mathrm{H} 3 \mathrm{~N} 2$ and $\mathrm{B}$ viruses were isolated from April through June $2005 .^{7}$ We defined two periods: one with limited circulating virus (September 2004 through January 2005) and one when the influenza virus was shown to be circulating (February through October 2005) (Figure 2). The randomization of mothers was successful overall in producing demographically similar maternal study groups; ${ }^{2}$ nevertheless, we tested for maldistribution in each study period of several factors likely to influence the effect of the vaccine on the fetus, including gestational age at immunization and delivery, the interval between maternal immunization and birth, and infant Apgar scores (Table 1). We also tested for distribution of maternal age, parity, height and weight three to four months after delivery.

Our seasonal analysis focused on the 116 infants born during the February-June 2005 period who were in utero for 22-94 days after maternal immunization while the influenza virus circulated.

We created a binary variable for study periods before and after Jan. 31, 2005, to distinguish the period with limited virus circulation from the period with proven virus circulation. We performed a formal test of interaction, followed by an analysis stratified by the influenza circulation period. Subgroup analysis of clinical trial data are often discouraged to avoid misleading results, particularly in the absence of an independent underlying biological model ${ }^{8}$ However, in studies of influenza virus infection and immunization, there is strong evidence for seasonality of the circulation of influenza virus and seasonality of antigenic matching of influenza vaccine with the circulating virus subtypes, ${ }^{9-13}$ providing substantial biologic support for this post-hoc analysis.

\section{Results}

During the study, 340 pregnant women were assigned to receive inactive influenza vaccine or pneumococcal vaccine (control) (Figure 1). In total, 336 infants were delivered, and 327 were included in our analysis. Three stillbirths occurred during the study period (December 2004, January and February 2005) among the mothers who received the influenza vaccine.

During the entire study period, $28 \%$ of infants in the influenza vaccine group were small for gestational age, and 38\% were small for gestational age in the control group (OR $0.63,95 \% \mathrm{CI}$ $0.4-1.0 ; p=0.05)$. The overall mean birth weight was $3 \%$ higher in the influenza vaccine group than in the control group (influenza vaccine 3117 g v. control $3027 \mathrm{~g} ; p=0.09$ ) (Table 2).

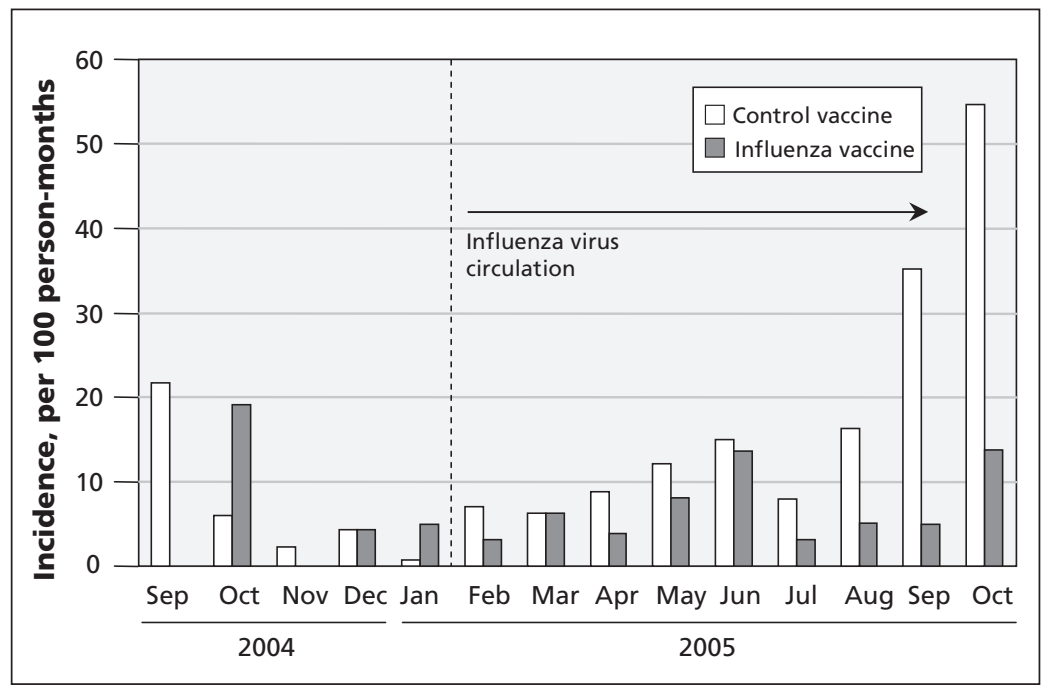

Figure 2: Incidence of respiratory illness with fever greater than $38^{\circ} \mathrm{C}$ among mothers and infants combined, and influenza virus before and after January 2005. 
During the period with limited virus circulation, there was no clinical effectiveness of the influenza vaccine on maternal plus infant respiratory illness (incidence rate ratio $0.99 ; p>0.9$ ) (Appendix 1 and 2, available at www.cmaj.ca /lookup/suppl/doi:10.1503/cmaj.110754/-/DC1). During the period with circulating influenza virus, the incidence rate ratio was 0.51 for all respiratory illness $(p=0.0003)$ (Table 3$)$. There was significant interaction for respiratory illness between vaccine groups and the period (limited or confirmed circulating influenza virus) $(p=0.02)$.
During the period with limited virus circulation, the proportion of infants who were small for gestational age was similar in both groups (influenza vaccine $29.1 \%$; control $34.3 \%$, OR 0.79 [95\% CI $0.44-1.41$ ]; $p=0.4$ ) (Table 4). In contrast, during the period with circulating virus and increased clinical effect of the influenza vaccine (Figure 2), the proportion of infants who were small for gestational age was $25.9 \%$ in the influenza vaccine group and $44.8 \%$ in the control group (OR 0.43, 95\% CI $0.20-0.94 ; p=0.03$ ) (Table 4). When we analyzed this data using the WHO growth standard, the OR was 0.39 (95\%

Table 1: Characteristics of mothers, by study period

\begin{tabular}{|c|c|c|c|}
\hline \multirow[b]{2}{*}{ Variable } & \multicolumn{2}{|c|}{ Mean $(95 \% \mathrm{Cl})$} & \multirow[b]{2}{*}{$p$ value } \\
\hline & Control vaccine & Influenza vaccine & \\
\hline $\begin{array}{l}\text { No influenza virus circulating } \\
\text { (Sept. 2004-Jan. 2005) }\end{array}$ & $n=108$ & $n=103$ & \\
\hline Gestational age at vaccination, wk & $31.9(31.6-32.3)$ & $31.9 \quad(31.5-32.2)$ & 0.8 \\
\hline Gestational age at delivery, wk & $39.3(38.9-39.6)$ & $39.4 \quad(39.1-39.8)$ & 0.6 \\
\hline $\begin{array}{l}\text { Interval between vaccination and } \\
\text { birth, } d\end{array}$ & $51.5(48.2-54.8)$ & $52.5 \quad(49.3-55.8)$ & 0.7 \\
\hline Age, yr & $25.0(24.4-25.8)$ & $25.5 \quad(24.6-26.3)$ & 0.4 \\
\hline Parity & $1.1(1.0-1.3)$ & $1.2(1.1-1.4)$ & 0.4 \\
\hline Height, $\mathrm{cm}$ & $152.5(151.2-153.8)$ & $153.1 \quad(151.9-154.1)$ & 0.5 \\
\hline Weight, * kg & $56.2(54.4-58.0)$ & $56.5 \quad(54.8-58.3)$ & 0.8 \\
\hline $\begin{array}{l}\text { Influenza virus circulating } \\
\text { (Feb. 2005-Oct. 2005) }\end{array}$ & $n=58$ & $n=58$ & \\
\hline Gestational age at vaccination, wk & $30.5(30.1-31.0)$ & 31.5 (31.0-32.0) & 0.01 \\
\hline Gestational age at delivery, wk & $39.7(39.3-40.1)$ & $39.7 \quad(39.3-40.1)$ & 0.9 \\
\hline $\begin{array}{l}\text { Interval between vaccination and } \\
\text { delivery, d }\end{array}$ & $63.9(59.8-68.0)$ & $57.4 \quad(53.8-61.1)$ & 0.02 \\
\hline Age, yr & $24.9(23.7-26.1)$ & $24.7 \quad(23.7-25.7)$ & 0.8 \\
\hline Parity & $1.3(1.0-1.5)$ & $0.9 \quad(0.7-1.1)$ & 0.1 \\
\hline Height, $\mathrm{cm}$ & $153.0(151.6-154.5)$ & $152.9(151.6-154.2)$ & 0.9 \\
\hline Weight, * kg & $54.0(51.4-56.7)$ & $53.9(51.8-55.9)$ & 0.9 \\
\hline
\end{tabular}

Table 2: Neonatal outcomes in overall study

\begin{tabular}{|lcccc} 
& \multicolumn{2}{c}{ No. (\%) of infants* } & & \\
\cline { 2 - 3 } Variable & $\begin{array}{c}\text { Control vaccine } \\
n=166\end{array}$ & $\begin{array}{c}\text { Influenza vaccine } \\
n=161\end{array}$ & $p$ value & OR $(95 \% \mathrm{Cl})$ \\
\hline Birth weight, mean, g & 3027 & 3117 & 0.09 & - \\
\hline Gestational age, mean, wk & 39.4 & 39.5 & 0.6 & - \\
\hline Small for gestational age & $63(38.0)$ & $45(28.0)$ & 0.05 & $0.63(0.4-1.0)$ \\
\hline Weighed less than < 2500 g & $13(7.8)$ & $1(4.4)$ & 0.2 & $0.53(0.2-1.4)$ \\
\hline Born before 37 weeks' gestation & $14(8.4)$ & $10(6.2)$ & 0.4 & $0.72(0.3-1.7)$ \\
\hline $\begin{array}{l}\text { Note: Cl = confidence interval, OR = odds ratio. } \\
\text { *Unless stated otherwise. }\end{array}$ & & & & \\
\hline
\end{tabular}


CI 0.16-0.92; $p=0.02$ ) (Appendix 3, available at www.cmaj.ca/lookup/suppl/doi:10.1503/cmaj .110754/-/DC1).

During the period with limited circulating virus, the mean birth weight was $3053 \mathrm{~g}$ in the influenza vaccine group and $3083 \mathrm{~g}$ in the control group ( $p=0.9)$. In contrast, during the period with circulating influenza virus, the mean

Table 3: Respiratory infections with fever greater than $38^{\circ} \mathrm{C}$ among mothers and infants combined, * by influenza period and vaccine group

\begin{tabular}{|c|c|c|c|c|c|c|}
\hline \multirow[b]{2}{*}{ Outcome } & \multicolumn{3}{|c|}{$\begin{array}{l}\text { No influenza virus circulating } \\
\text { (Sept. 2004-Jan. 2005) }\end{array}$} & \multicolumn{3}{|c|}{$\begin{array}{l}\text { Influenza virus circulating } \\
\quad \text { (Feb. 2005-Oct. 2005) }\end{array}$} \\
\hline & $\begin{array}{l}\text { Control } \\
n=216\end{array}$ & $\begin{array}{c}\text { Influenza } \\
n=206\end{array}$ & $\begin{array}{c}p \\
\text { value }\end{array}$ & $\begin{array}{l}\text { Control } \\
n=116\end{array}$ & $\begin{array}{c}\text { Influenza } \\
n=116\end{array}$ & $\begin{array}{c}p \\
\text { value }\end{array}$ \\
\hline $\begin{array}{l}\text { Episodes of respiratory illness } \\
\text { with fever, no. }\end{array}$ & 37 & 36 & & 73 & 39 & \\
\hline Person-months & 932 & 914 & & 1014 & 1053 & \\
\hline $\begin{array}{l}\text { Incidence/100 person-months } \\
(95 \% \mathrm{Cl})\end{array}$ & $4.0(2.8$ to 5.5$)$ & 3.9 (2.8 to 5.5$)$ & & $7.2(5.6$ to 9.1$)$ & $3.7(2.6$ to 5.1$)$ & \\
\hline Incidence difference $(95 \% \mathrm{Cl})$ & \multicolumn{2}{|c|}{$-0.03(-1.9$ to 1.8$)$} & \multicolumn{4}{|c|}{$-3.5(-5.5$ to -1.5$)$} \\
\hline Incidence rate ratio $(95 \% \mathrm{Cl})$ & \multicolumn{2}{|c|}{0.99 (0.63 to 1.57$)$} & $>0.9$ & \multicolumn{2}{|c|}{$0.51(0.4$ to 0.8$)$} & 0.0003 \\
\hline
\end{tabular}

Table 4: Neonatal outcomes, by study period

\begin{tabular}{|c|c|c|c|c|c|c|c|c|}
\hline \multirow[b]{2}{*}{ Variable } & \multicolumn{2}{|r|}{ Control vaccine } & \multicolumn{2}{|r|}{ Influenza vaccine } & \multirow[b]{2}{*}{ OR $(95 \% \mathrm{Cl}) *$} & \multirow{2}{*}{$\begin{array}{c}p \\
\text { value }\end{array}$} & \multirow{2}{*}{$\begin{array}{c}\text { Adjusted OR } \\
(95 \% \mathrm{Cl})^{\star} \dagger\end{array}$} & \multirow{2}{*}{$\begin{array}{l}p \\
\text { value } \neq\end{array}$} \\
\hline & No. & $\%(95 \% \mathrm{Cl}) *$ & No. & $\%(95 \% \mathrm{Cl}) *$ & & & & \\
\hline Birth weight, g, mean & - & 3053 (2967 to 3139) & - & 3083 (3000 to 3176) & $30(-98$ to 157$)$ ** & $0.9+\dagger$ & - & \\
\hline Weight $<2500 \mathrm{~g}$ & 8 & $7.4(2.5$ to 12.3$)$ & 6 & $5.8(1.3$ to 10.3$)$ & 0.77 (0.26 to 2.31$)$ & 0.6 & - & \\
\hline $\begin{array}{l}\text { Apgar score at } 1 \mathrm{~min} \text {, } \\
\text { mean }\end{array}$ & - & 7.7 (7.3 to 8.1$)$ & - & 7.6 (7.3 to 8.1$)$ & - & 0.7 & - & \\
\hline Female & $46 ף$ & 42.9 (32.7 to 51.3$)$ & 43 & 41.8 (31.5 to 50.5$)$ & 0.97 (0.56 to 1.67$)$ & 0.9 & - & \\
\hline Small for gestational age§ & 26 & 44.8 (31.2 to 56.8$)$ & 15 & $25.9(13.9$ to 36.1$)$ & $0.43(0.20$ to 0.94$)$ & 0.03 & $0.44(0.19$ to 0.99$)$ & 0.05 \\
\hline $\begin{array}{l}\text { Born before } 37 \text { weeks' } \\
\text { gestation }\end{array}$ & 4 & $6.9(0.4$ to 13.4$)$ & 2 & 3.5 (0 to 8.2 ) & 0.48 (0.08 to 2.74$)$ & 0.4 & $0.32(0.05$ to 2.29$) \S \S$ & 0.3 \\
\hline Weight $<2500 \mathrm{~g}$ & 5 & $8.6(1.4$ to 15.8$)$ & 1 & $1.7(0$ to 5.0$)$ & $0.19(0.02$ to 1.64$)$ & 0.09 & $0.17(0.02$ to 1.63$)$ & 0.1 \\
\hline $\begin{array}{l}\text { Apgar score at } 1 \mathrm{~min} \text {, } \\
\text { mean }\end{array}$ & - & 7.3 (6.6 to 8.0$)$ & - & 7.7 (7.3 to 8.2$)$ & - & 0.3 & - & \\
\hline Female & 26 & 44.8 (31.2 to 56.8$)$ & 27 & 46.6 (33.2 to 58.9$)$ & 1.07 (0.52 to 2.23$)$ & 0.9 & 1.12 (0.53 to 2.39$)$ & 0.8 \\
\hline 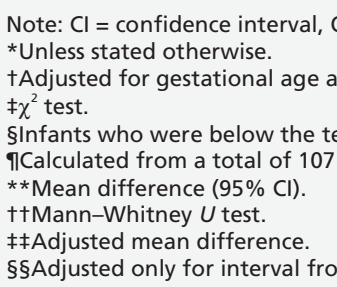 & $\begin{array}{l}\text { imm } \\
\text { enth } p \\
\text { infant } \\
\text { m imn }\end{array}$ & $\begin{array}{l}\text { dds ratio. } \\
\text { unization, and interval fro } \\
\text { ercentile of weight for ge } \\
\text { s due to missing sex data } \\
\text { unization to delivery. }\end{array}$ & $\begin{array}{l}\text { tation } \\
\text { or one }\end{array}$ & $\begin{array}{l}\text { unization to delivery. } \\
\text { age. } \\
\text { infant. }\end{array}$ & & & & \\
\hline
\end{tabular}


birth weight was $3178 \mathrm{~g}$ in the influenza vaccine group and $7 \%$ higher than $2978 \mathrm{~g}$ in the control group ( $p=0.02$ ) (Table 4, Figure 3 ).

Figure 3 shows that, during the period with limited circulating influenza virus, the distribution of birth weight was similar in the two groups (Mann-Whitney $U$ test, $p=0.9$ ). In contrast, during the period with circulating virus, there was a shift in the distribution of birth weight to higher values among infants born to mothers vaccinated against influenza (MannWhitney $U$ test, $p=0.02$ ).

We did not detect a difference in the rate of premature births between the influenza vaccine and control groups when there was circulating influenza virus $(3.5 \%$ v. $6.9 \%$; OR 0.48 [95\% CI $0.08-2.74] ; p=0.4$ ) (Table 4). Although the

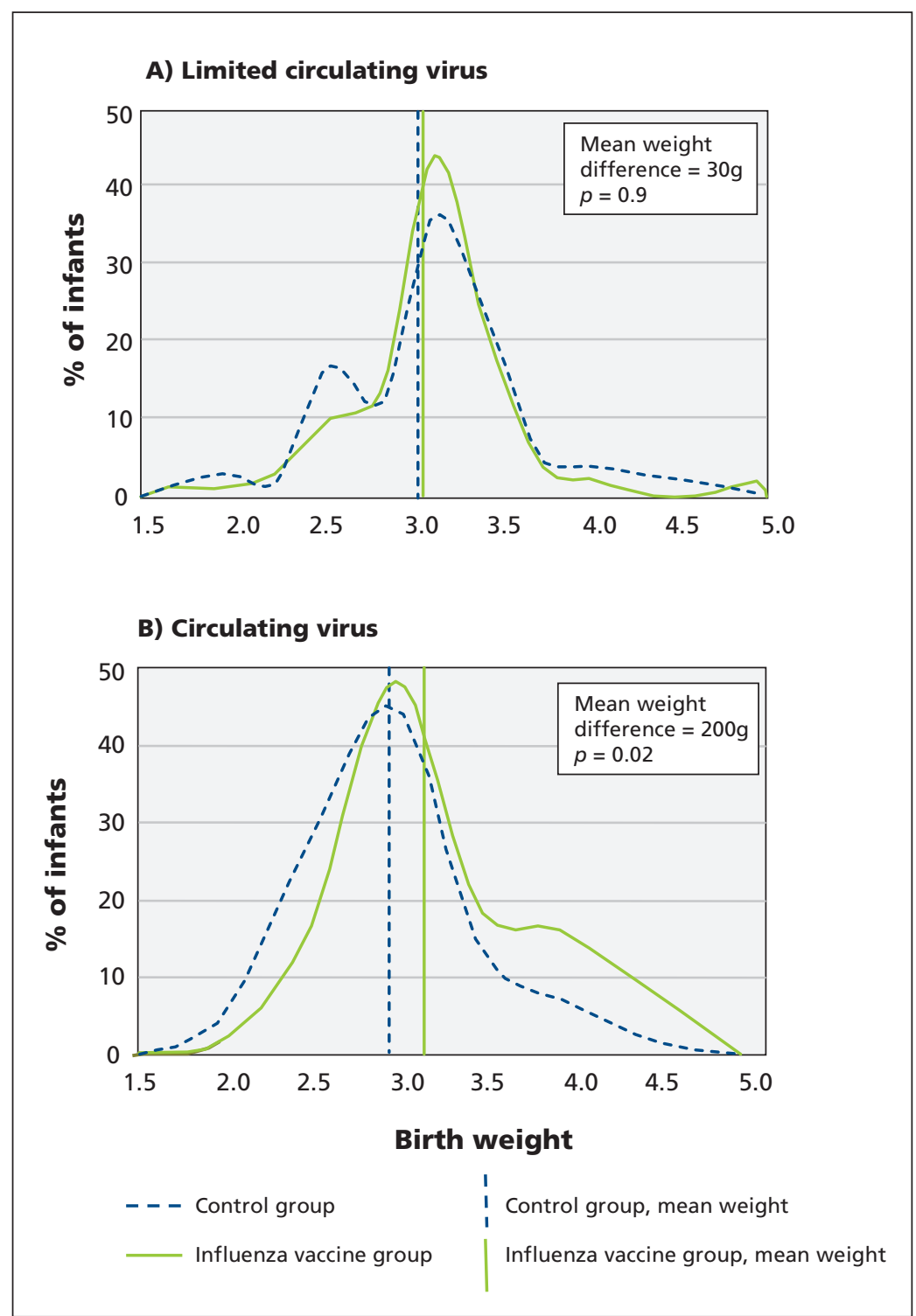

Figure 3: Distribution of birth weight by group and period. Periods of influenza virus circulation: A) limited circulation, October 2004 through January 2005; B) confirmed circulation, February through October 2005. number of infants with a low birth weight was small during the period with circulating influenza virus, there were fewer infants who weighed less than $2500 \mathrm{~g}$ in the influenza vaccine group $(1.7 \%)$ than in the control group $(8.6 \%)$; however, this difference was not significant (OR 0.19 [95\% CI 0.02-1.64]; $p=0.09$ ).

During the period with circulating influenza virus, the mean gestational age of the fetus when the mother was vaccinated was greater and the mean interval from immunization to birth was six days shorter in the influenza vaccine group than in the control group (Table 1), suggesting that, for the mothers who received influenza vaccine, there were fewer days available for the generation of a maternal immune response and for transplacental antibody transfer to the fetus, possibly limiting the observed effect of influenza vaccine for some study outcomes.

We performed multiple logistic regression to estimate adjusted ORs for small for gestational age after accounting for the effect of gestational age at immunization and the interval between immunization to birth. The adjusted ORs are similar to the unadjusted ones (Table 4). During the period with circulating influenza virus, the ORs were somewhat lower. Similarly, we performed multiple linear regression to estimate birth weight adjusted for gestational age at immunization and the interval between immunization and delivery. The adjusted birth weights were similar in magnitude to the unadjusted birth weights (Table 4). There were no significant differences between the influenza vaccine group and the control group in the distribution of infant gestational age at birth, Apgar score or the maternal characteristics of age, parity, height and postpartum weight (Table 1 and 2).

\section{Interpretation}

We found that immunization against influenza during pregnancy had a substantial effect on mean birth weight and the proportion of infants who were small for gestational age but only during the period of increased circulating influenza virus in the community.

Our data suggest that the prevention of infection with seasonal influenza in pregnant women by immunization can influence fetal growth. It has been reported that infection with pandemic influenza virus has substantial adverse effects in pregnant women and fetuses $;^{14-18}$ however, there are limited similar data from epidemic seasonal influenza illness. ${ }^{3}$

The chronology of the specific effect of influenza vaccine on mean birth weight that we describe is distinct from the previously described 
general seasonality of birth weights in Bangladesh. Studies from Bangladesh have shown a seasonal pattern of reduction in the mean birth weights of full-term infants and an increase in the number of preterm infants in the season called monga, September to November, associated with reduced food availability before the annual harvest. ${ }^{19}$

There have been only four reports of infection of the fetus or placenta with nonpandemic influenza viruses, suggesting that this may be an infrequent event. ${ }^{20-23}$ The fetus gains $35-40 \mathrm{~g} / \mathrm{d}$ ( $1 \%$ of birth weight) in the last month of gestation. ${ }^{24}$ Several days of maternal illness, including fever, anorexia $\mathrm{a}^{25}$ and circulating proinflammatory cytokines, ${ }^{26}$ even without severe maternal respiratory illness or admission to hospital, may account for the fetal effects we observed. The maternal generalized inflammatory responses to infection with the influenza virus likely modulates maternal metabolism, placental function and the transfer of nutrients to the fetus. The circulating maternal proinflammatory chemokines, cytokines and other factors ${ }^{27-29}$ may cross the placenta and have indirect inflammatory and metabolic effects in the fetus. The mechanisms of the effect of maternal influenza on fetal growth have not been described, and studies of the pathogenesis of this antenatal infection should be undertaken to elucidate approaches to treatment and prevention.

Several retrospective hospital record reviews and case-control studies have reported that infants born to mothers infected or exposed to influenza have mean birth weights similar to a variety of controls, but these observational assessments were not randomized trials $\mathrm{s}^{30-33}$ and may not have captured the effects of influenza vaccine because of bias in the selection of cases or controls.

Several prospective randomized controlled trials of a variety of interventions for infectious illnesses in pregnant women have shown an increase in mean birth weight similar to the effect size we observed. For example, the use of malaria prophylaxis or antibiotic therapy in mothers with infections increased mean birth weight by $155-159$ g. ${ }^{34,35}$ Randomized controlled trials of nutritional interventions in low resource settings have shown significant increases in mean birth weight, ranging from 70 to $200 \mathrm{~g}^{36-39}$ A case-control assessment showed that prepartum pneumonia resulting in admission to hospital was associated with a $391 \mathrm{~g}$ reduction in mean birth weight. ${ }^{40}$

A recent retrospective observation of the effect of influenza vaccine in Georgia, United States, showed that the likelihood of small-forgestational-age infants born to women who had been vaccinated against influenza was reduced by $69 \%$ during a period of widespread influenza activity. ${ }^{41}$ Several studies in North America and the United Kingdom of influenza-like ilnesses ${ }^{42}$ or proven influenza illness ${ }^{43,44}$ have reported significant reductions in mean birth weight, ranging from 90 to $285 \mathrm{~g}$.

\section{Strengths and limitations}

The strengths of our study include the randomized double-blind design, the intention-to-treat analysis, the close observation of the participants and the monitoring of influenza infections in infants. The use of two growth standards with similar results provides some confidence about our observations. Because there is no Bangladesh reference for weight for gestational age, we used a North American standard. ${ }^{5}$ Many consider this reference population of a variety of ethnic groups, with relatively low levels of nutritional deprivation, to be a good reference for assessment of fetal growth potential.

Because the study outcomes were specified a priori, we did not correct for multiple comparisons in this analysis. Therefore, this secondary analysis may have some results that represent type I errors. In addition, the relatively small number of observations in 116 infants potentially exposed to maternal influenza infection during gestation may mean that some of our estimates are not precise.

We used clinical observations of maternal influenza-like illness, and we do not have supporting virologic data. The reduction of influenza-like febrile illness among the vaccinated women mirrored the reduction in laboratory-confirmed cases of influenza in their infants in the same household. ${ }^{2}$ The reduction of influenza-like febrile illness during periods with circulating influenza virus is accepted as a valid surrogate indicator for the effectiveness of influenza vaccine. ${ }^{10,13}$

The pneumococcal vaccine that was used as a control may have had an independent positive effect on the outcomes among infants. If that were the case, the observed difference between the two vaccine groups would be an underestimate of the true effect of influenza vaccine compared with placebo.

Our assessment of the effect of the influenza vaccine was carried out for about one year. This year may not be typical of every year, especially with respect to local circulation of several influenza virus strains in tropical regions. ${ }^{7}$

\section{Conclusion}

Our data suggest that influenza infection during pregnancy may affect fetal development. The overall absolute reduction in the proportion of 
infants who were small for gestational age was 0.1 , suggesting that every 10 maternal influenza immunizations prevented the birth of one smallfor-gestational-age infant. During the period with local circulation of influenza virus, the number needed to vaccinate to prevent one small-for-gestational-age birth is six mothers.

There is substantial data to show that fullterm infants who are small for gestational age have an increased risk of lifelong consequences. ${ }^{45-47}$ Effective, safe vaccines to prevent influenza during pregnancy are available and recommended by a variety of agencies. ${ }^{48-51}$ Antenatal programs to vaccinate against tetanus in limited-resource regions have achieved a substantial level of coverage, reaching, for example, $80 \%$ of all pregnant women in Bangladesh..$^{52}$ If our data about the effect of antenatal influenza immunization on fetal development are confirmed, the existence of effective antenatal immunization delivery systems suggests influenza vaccine may be a feasible addition to routine antenatal immunization programs.

\section{References}

1. Poehling KA, Edwards KM, Weinberg GA, et al. The underrecognized burden of influenza in young children. $N$ Engl $\mathrm{J} \mathrm{Med}$ 2006;355:31-40.

2. Zaman K, Roy E, Arifeen SE, et al. Effectiveness of maternal influenza immunization in mothers and infants. $N$ Engl $\mathrm{J}$ Med 2008;359:1555-64.

3. Mak TK, Mangtani P, Leese J, et al. Influenza vaccination in pregnancy: current evidence and selected national policies. Lancet Infect Dis 2008;8:44-52

4. Goldenberg RL, Culhane JF, Johnson DC. Maternal infection and adverse fetal and neonatal outcomes. Clin Perinatol 2005; 32:523-59.

5. Oken E, Kleinman KP, Rich-Edwards J, et al. A nearly continuous measure of birth weight for gestational age using a United States national reference. BMC Pediatr 2003;3:6.

6. WHO Multicentre Growth Reference Study Group. WHO child growth standards: methods and development. Geneva (Switzerland): World Health Organization; 2006. Available: www.who .int/childgrowth/standards/technical_report/en/ (accessed 2011 Nov. 15).

7. Brooks WA, Goswami D, Rahman M, et al. Influenza is a major contributor to childhood pneumonia in a tropical developing country. Pediatr Infect Dis J 2010;29:216-21.

8. Wang R, Lagakos SW, Ware JH, et al. Statistics in medicine reporting of subgroup analyses in clinical trials. $N$ Engl J Med 2007:357:2189-94.

9. Belongia EA, Kieke BA, Donahue JG, et al. Effectiveness of inactivated influenza vaccines varied substantially with antigenic match from the 2004-2005 season to the 2006-2007 season. J Infect Dis 2009;199:159-67.

10. Belshe RB, Mendelman PM, Treanor J, et al. The efficacy of live attenuated, cold-adapted, trivalent, intranasal influenzavirus vaccine in children. N Engl J Med 1998;338:1405-12.

11. Carrat F, Flahault A. Influenza vaccine: the challenge of antigenic drift. Vaccine 2007;25:6852-62.

12. Herrera GA, Iwane MK, Cortese M, et al. Influenza vaccine effectiveness among 50-64-year-old persons during a season of poor antigenic match between vaccine and circulating influenza virus strains: Colorado, United States, 2003-2004. Vaccine 2007; 25:154-60.

13. Jackson LA. Using surveillance to evaluate influenza vaccine effectiveness. J Infect Dis 2009;199:155-8.

14. Creanga AA, Johnson TF, Graitcer SB, et al. Severity of 2009 pandemic influenza A $(\mathrm{H} 1 \mathrm{~N} 1)$ virus infection in pregnant women. Obstet Gynecol 2010;115:717-26.

15. Harris J. Influenza occurring in pregnant women. JAMA 1919; 72:978-80.

16. Jamieson DJ, Honein MA, Rasmussen SA, et al. H1N1 2009 influenza virus infection during pregnancy in the USA. Lancet 2009;374:451-8

17. Siston AM, Rasmussen SA, Honein MA, et al. Pandemic 2009 influenza $\mathrm{A}(\mathrm{H} 1 \mathrm{~N} 1)$ virus illness among pregnant women in the United States. JAMA 2010;303:1517-25.

18. Woolston W. Epidemic pneumonia (Spanish Influenza) in pregnancy: effect in one hundred and one cases. JAMA 1918;71:1998-9.

19. Hort KP. Seasonal variation of birthweight in Bangladesh. Ann Trop Paediatr 1987;7:66-71.

20. Yawn DH, Pyeatte JC, Joseph JM, et al. Transplacental transfer of influenza virus. JAMA 1971;216:1022-3.

21. Lieberman RW, Bagdasarian N, Thomas D, et al. Seasonal influenza A (H1N1) infection in early pregnancy and second trimester fetal demise. Emerg Infect Dis 2011;17:107-9.

22. McGregor JA, Burns JC, Levin MJ, et al. Transplacental passage of influenza A/Bangkok (H3N2) mimicking amniotic fluid infection syndrome. Am J Obstet Gynecol 1984;149:856-9.

23. Mel'nikova VF, Tsinzerling AV, Aksenov OA, et al. [Involvement of the afterbirth in influenza] [article in Russian]. Arkh Patol 1987;49:19-25.

24. Usher RH, McLean FH. Normal fetal growth and the significance of fetal growth retardation. In: Davis JA, Dobbins J, editors. Scientific foundations of paediatrics. Philadelphia (PA): Saunders; 1974. p. 69-80.

25. Langhans W. Anorexia of infection: current prospects. Nutrition 2000;16:996-1005.

26. Eccles R. Understanding the symptoms of the common cold and influenza. Lancet Infect Dis 2005;5:718-25.

27. Brydon EW, Morris SJ, Sweet C. Role of apoptosis and cytokines in influenza virus morbidity. FEMS Microbiol Rev 2005;29:837-50.

28. Kaiser L, Fritz RS, Straus SE, et al. Symptom pathogenesis during acute influenza: interleukin- 6 and other cytokine responses. J Med Virol 2001;64:262-8.

29. Zhou J, Law HK, Cheung CY, et al. Differential expression of chemokines and their receptors in adult and neonatal macrophages infected with human or avian influenza viruses. $J$ Infect Dis 2006;194:61-70.

30. Acs N, Banhidy F, Puho E, et al. Pregnancy complications and delivery outcomes of pregnant women with influenza. J Matern Fetal Neonatal Med 2006;19:135-40.

31. Griffiths PD, Ronalds CJ, Heath RB. A prospective study of influenza infections during pregnancy. J Epidemiol Community Health 1980;34:124-8

32. Hartert TV, Neuzil KM, Shintani AK, et al. Maternal morbidity and perinatal outcomes among pregnant women with respiratory hospitalizations during influenza season. Am J Obstet Gynecol 2003; 189:1705-12.

33. Irving WL, James DK, Stephenson T, et al. Influenza virus infection in the second and third trimesters of pregnancy: a clinical and seroepidemiological study. BJOG 2000;107:1282-9.

34. Gichangi PB, Ndinya-Achola JO, Ombete J, et al. Antimicrobial prophylaxis in pregnancy: a randomized, placebo-controlled trial with cefetamet-pivoxil in pregnant women with a poor obstetric history. Am J Obstet Gynecol 1997;177:680-4.

35. Greenwood B. The use of anti-malarial drugs to prevent malaria in the population of malaria-endemic areas. Am J Trop Med Hyg 2004;70:1-7.

36. Abu-Saad K, Fraser D. Maternal nutrition and birth outcomes. Epidemiol Rev 2010;32:5-25.

37. Christian P, Darmstadt GL, Wu L, et al. The effect of maternal micronutrient supplementation on early neonatal morbidity in rural Nepal: a randomised, controlled, community trial. Arch Dis Child 2008;93:660-4.

38. Christian P, Khatry SK, Katz J, et al. Effects of alternative maternal micronutrient supplements on low birth weight in rural Nepal: double blind randomised community trial. BMJ 2003; 326:571.

39. Lechtig A, Habicht JP, Delgado H, et al. Effect of food supplementation during pregnancy on birthweight. Pediatrics 1975;56: 508-20.

40. Munn MB, Groome LJ, Atterbury JL, et al. Pneumonia as a complication of pregnancy. J Matern Fetal Med 1999;8:151-4.

41. Omer SB, Goodman D, Steinhoff MC, et al. Maternal influenza immunization and reduced likelihood of prematurity and small for gestational age births: a retrospective cohort study. PLoS Med 2011;8:e1000441

42. McNeil SA, Dodds LA, Fell DB, et al. Effect of respiratory hospitalization during pregnancy on infant outcomes. Am J Obstet Gynecol 2011;204:54S-57S.

43. Pierce M, Kurinczuk JJ, Spark P, et al. Perinatal outcomes after maternal 2009/H1N1 infection: national cohort study. BMJ 2011;342:d3214. 
44. Mendez-Figueroa H, Raker C, Anderson BL. Neonatal characteristics and outcomes of pregnancies complicated by influenza infection during the 2009 pandemic. Am J Obstet Gynecol 2011; 204(Suppl 1):58-63.

45. Lundgren EM, Tuvemo T. Effects of being born small for gestational age on long-term intellectual performance. Best Pract Res Clin Endocrinol Metab 2008;22:477-88.

46. Sommerfelt K, Andersson HW, Sonnander K, et al. Cognitive development of term small for gestational age children at five years of age. Arch Dis Child 2000;83:25-30.

47. Gluckman PD, Hanson MA, Cooper C, et al. Effect of in utero and early-life conditions on adult health and disease. $N$ Engl $J$ Med 2008;359:61-73.

48. Influenza vaccines. Wkly Epidemiol Rec 2005;80:279-87.

49. National Advisory Committee on Immunization (NACI). Statement on influenza vaccination for the 2008-2009 season. An Advisory Committee Statement (ACS). Can Commun Dis Rep 2008;34:1-46.

50. Fiore AE, Shay DK, Broder K, et al. Prevention and control of influenza: recommendations of the Advisory Committee on Immunization Practices (ACIP), 2008. MMWR Recomm Rep 2008;57(RR-7):1-60.

51. H1N1 (2009) winter flu: Updated advice for providers of maternity services. London (UK): Department of Health, Health Protection Agency; 2011

52. Ortiz JR, Englund JA, Neuzil KM. Influenza vaccine for pregnant women in resource-constrained countries: a review of the evidence to inform policy decisions. Vaccine 2011;29:4439-52.

Affiliations: From the Bloomberg School of Public Health (Steinhoff), Johns Hopkins University, Baltimore, Md.; the Cincinnati Children's Hospital Medical Center (Steinhoff, Dodd), Cincinnati, Ohio; the Rollins School of Public Health (Omer), Emory University, Atlanta, Ga.; the Center for Health Research — Southeast, Kaiser Permanente, Atlanta, Ga.; the International Centre for Diarrheal Disease Research (Roy, Arifeen, Raqib, Zaman), Dhaka, Bangladesh; and the Centers for Disease Control and Prevention (Breiman), Atlanta, Ga.
Contributors: Mark Steinhoff had full access to all of the data in the study and takes responsibility for the integrity of the data and the accuracy of the data analysis. Mark Steinhoff, Saad Omer, K. Zaman, Eliza Roy, Shams Arifeen and Robert Breiman designed the study. Eliza Roy, K. Zaman, Shams Arifeen and Rubhana Raqib acquired the data. Mark Steinhoff, K. Zaman, Eliza Roy, Caitlan Dodd, Saad Omer and Shams Arifeen performed the analysis and interpretation of data. Mark Steinhoff, Saad Omer and Caitlan Dodd performed the statistical analysis. Mark Steinhoff, Saad Omer, K. Zaman and Robert Breiman drafted the manuscript, which was critically revised by Mark Steinhoff, Saad Omer, K. Zaman, Eliza Roy, Robert Breiman and Rubhana Raqib. Shams Arifeen, K Zaman and Mark Steinhoff provided administrative, technical or material support. K. Zaman and Mark Steinhoff supervised the study. All of the authors approved the final version of the manuscript submitted for publication.

Funding: The Mother'sGift project was supported by the Bill and Melinda Gates Foundation; the United States Agency for International Development; Wyeth Pharmaceuticals Inc.; the Thrasher Research Fund; Aventis Pasteur; the International Centre for Diarrheal Disease Research, Bangladesh; and the Bloomberg School of Public Health at Johns Hopkins University.

Dr. Omer was awarded the Maurice R. Hilleman EarlyStage Career Investigator Award by the National Foundation for Infectious Diseases (NFID). The award was funded by an unrestricted educational grant to the NFID from Merck Co. Inc.; however, Dr. Omer had no direct interaction with Merck Co. Inc.

Acknowledgements: The authors thank the field and data management team at the International Centre for Diarrheal Disease Research, Bangladesh, for their efforts. The authors thank Dr. David Sack for his invaluable assistance in the project.

\section{Comment VOUS pouvez vous impliquer dans l'AMC Votre participation peut faire la différence}

The CMA is committed to providing leadership for physicians and promoting the highest standard of health and health care for Canadians. To strengthen the association and truly represent all Canadian physicians, the CMA needs to hear from members interested in service - both in elected positions and on committees and advisory groups.

For further information on how you can get involved visit our website at cma.ca/membercentre/how-youcan-get-involved or contact Julie Perron at julie.perron@cma.ca or 800 663-7336 x2243.
L'AMC est vouée à jouer un rôle de chef de file auprès des médecins et à promouvoir les normes les plus élevées de santé et de soins de santé pour les Canadiens. Afin de renforcer l'Association et pour qu'elle représente véritablement tous les médecins du Canada, l'AMC a besoin de membres intéressés à occuper des charges élves et à siéger à des comités et des groupes consultatifs.

Pour en savoir davantage sur les modalités de participation visiter notre site web à cma.ca/centre desmembres/comment-vous-impliquer-dans-lamc ou communiqué avec Julie Perron à julie.perron@cma.ca ou 800 663-7336, poste 2243.

ASSOCIATION
MÉDICALE
CANADIENNE

